\title{
Transient Receptor Potential Cation Channel Subfamily M Member 3
}

National Cancer Institute

\section{Source}

National Cancer Institute. Transient Receptor Potential Cation Channel Subfamily M

Member 3. NCI Thesaurus. Code C124911.

Transient receptor potential cation channel subfamily M member 3 (1732 aa, 198 kDa)

is encoded by the human TRPM3 gene. This protein is involved in calcium internalization. 